\title{
Degradation profile of synthetic coral scaffold in cell culture media
}

\author{
Erlina Sih Mahanani ${ }^{1,{ }^{*}}$ and Dwi Rizki Lestari ${ }^{2}$ \\ 1 School of Dentistry, Faculty of Medicine and Health Science, Universitas \\ Muhammadiyah Yogyakarta, Tamantirto, Yogyakarta, Indonesia \\ 2 RSGM Universitas Muhammadiyah Yogyakarta, Jl. HOS Cokroaminoto 17, Wirobrajan, \\ Yogyakarta, Indonesia \\ *e-mail: erlina.sih@umy.ac.id
}

\begin{abstract}
The scaffold is one of the factors in tissue engineering that determine the success of bone regeneration. The important characteristic of the scaffold is able to degrade gradually. In vitro study using cells, the scaffold will be exposed to culture media. Therefore, degradation profile for scaffold needs to be examined. This study aims to investigate the degradation profile of synthetic coral scaffold in cell culture media using $\mathrm{pH}$ measurement. The method used the synthetic coral scaffolds were prepared from denaturalized collagen (gelatin) and calcium carbonate (calcite) with a concentration of 5:5 and 4:6 weight $\%$ in aqua dest. The scaffolds were fabricated in membrane thick film which was then physically crosslinked. The $10 \%$ of gelatin scaffold was used as a control. The scaffolds were incubated in cell culture media (non-phenol red Dulbecco's Modified Eagle Medium) for 1 until 8 days, and $\mathrm{pH}$ changes of the medium were measured. As the result, Profile of degradation on day 1 to day 4 showed the 5:5 scaffold had the smallest degradation. The results indicated the significant different between scaffold concentration in day $1(p=0.005), 5^{\text {th }}$ $(p=0.03)$, and 6th day $(p=0.011)$. At the end of incubated days, the $\mathrm{pH}$ changed but not significantly different. LSD showed the significant differences between scaffold (5:5 and 4:6) with control and no significant difference between 2 concentrations of the scaffold. The conclusion of this study is the synthetic coral scaffold degraded gradually until the end incubation time and between concentration had different degradation profile in the early incubation time using $\mathrm{pH}$ measurement.
\end{abstract}

\section{Keywords}

Citation: Mahanani, E. S., \& Lestari, D. R. (2018). Degradation profile of synthetic coral scaffold in cell culture media. In F. Jajah \& $\mathrm{H}$. Susilowati (Eds.), UGM Digital Press Health Sciences: Vol. 1. Proceeding of the $2^{\text {nd }}$ International Conference on Health Sciences, (pp. 7-11).

Published: October, 2018

bone regeneration, degradation, non-phenol red DMEM, synthetic coral scaffold

\section{Introduction}

The reconstruction of critical defects of alveolar bone damage requires surgical treatment. One of the methods is by reconstructing tissue and organ transplantation. However, this method has some limitations. Medical equipment for reconstructive surgery is unable to replace the full body's biological function. Organ transplantation also has limitation since the organ or the donor tissue has a short life and it 
requires the patient to consume immunosuppressant to prevent reaction of immune rejection. Thus, it needs a new treatment which is clinically acceptable for patients [1].

Tissue engineering is a technique which has been developed recently and has potential to regenerate new tissue formation. The successfully of Tissue engineering requires three components: scaffold, cell, and growth factor. Cells will proliferate, migrate and differentiate into specialized cells. Cells will be induced by molecule signal or growth factors to produce the matrix extracellular which is essential for tissue formation [2]. Scaffold has an important role in the success of tissue engineering because it must have biological nature such as being biocompatible and biodegradable as well as having high strength and porosity [3]. The speed of scaffold degradation must be in accordance with the time required by the cell to build a new tissue formation [4].

Various materials can be used as the basic materials of the scaffold, one of them is gelatin. Gelatin is a denatured collagen which can be gotten from skin, bone, and connecting tissue. Gelatin is used as one of the basic materials because of its nature which is biocompatible, biodegradable and has low antigenicity. Scaffold with has gelatin as its base material has quick degradation by enzymes, so gelatin scaffold requires modification by combining other materials or crosslinking to slow down the degradation [5].

In recent years, coral is a material that is frequently used as a scaffold to regenerate bone tissues. Coral contains calcium carbonate which serves as the main substituting material for bone and can be processed into the desired form and size. Previous research has shown that coral has good biocompatibility and osteoinduction, can be absorbed and function as a delivery system of bone growth factor [6]. Coral is very potential as a scaffold for tissue engineering, but it is a protected ecosystem because it functions to keep the habitat of sea life in balance. Based on that consideration, the scaffold is developed like coral which contains gelatin and $\mathrm{CaCO} 3$ as the basic materials. Coral is very potential as a scaffold for tissue engineering, but it is a protected ecosystem because it functions to keep the habitat of sea life in balance. Based on that consideration, the synthetic coral scaffold is developed similar to coral which contains gelatin and $\mathrm{CaCO} 3$ as the basic materials [7].

This synthetic coral scaffold will be used to regenerate damaged bone tissues using tissue engineering techniques. It needs cells requiring cells (in this case stem cells) that will proliferate, differentiate into bone cells and form the new bone for regenerating bone damage. Therefore, it is necessary to study how scaffold degradation occurs in the media used as cell culture.

\section{Methods}

The synthetic coral scaffold was developed from gelatin and calcium carbonate. The composition of gelatin: calcium carbonate that is used are 5:5; 4:6 by weight, and $10 \%$ gelatin as a control. After fabrication process, physical crosslinking was done to strengthen the structure7a. Cell culture media used non-phenol red Dulbecco's Modified Eagle Medium (Gibco, USA).

The samples of this research consisted of 12 samples, each scaffold composition consisted of 3 samples, and cell culture medium without scaffold. Scaffold with various compositions was immersed in 6 $\mathrm{ml}$ solution of cell culture media for each sample and was incubated at the temperature of $37^{\circ} \mathrm{C}$. Immersed solution $\mathrm{pH}$ (culture cell media) was measured daily using digital meter $\mathrm{pH}$. The more alkaline the $\mathrm{pH}$ solution, the higher the degradation would be. The measurement was done every 3 pm until the solution of immersion became dry. Data analysis was conducted using SPSS.17 with One Way Anova and continued with Post Hoc test.

\section{Results}

The synthetic coral scaffold was fabricated as thick like a film with interconnected porosity (Fig. 1) shown by scanning electron microscope. Table 1 presented the $\mathrm{pH}$ of scaffold degradation among groups. These results indicated increasing degradation from day 1 to day 8, meaning the degradability occurred with time. It also indicates by degradation profile in Fig. 2. The significant difference between day immersion are presented on day 1,5 , and 6 (Table 2). 


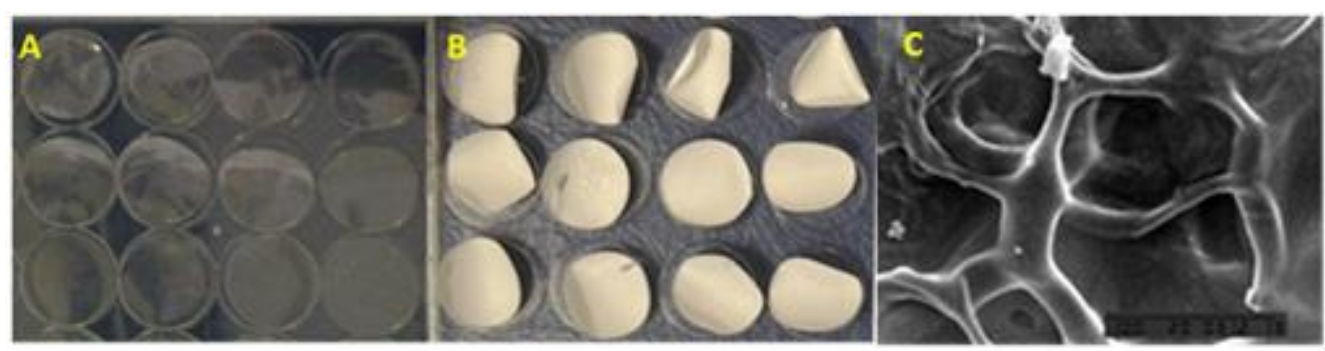

Fig. 1 A thick film like scaffold and SEM. A gelatin $10 \%$, B gelatin: calcium carbonate (5:5 and 4:6), C scanning electron microscope of the synthetic coral scaffold (4:6 concentration)

Table $1 \mathrm{pH}$ of cell culture medium

\begin{tabular}{ccccccccc}
\hline Scaffold & \multicolumn{7}{c}{$\mathrm{pH}$ of cell culture medium } \\
\cline { 2 - 9 } & 1 & 2 & 3 & 4 & 5 & 6 & 7 & 8 \\
\hline 5.5 & $0.20 \pm 0.08$ & $0.37 \pm 0.17$ & $0.48 \pm 0.65$ & $1.00 \pm 0.22$ & $1.34 \pm 0.02$ & $1.48 \pm 0.03$ & $1.61 \pm 0.03$ & $1.66 \pm 0.04$ \\
$4: 6$ & $0.12 \pm 0.07$ & $0.63 \pm 0.39$ & $0.98 \pm 0.04$ & $1.28 \pm 0.03$ & $1.39 \pm 0.02$ & $1.43 \pm 0.07$ & $1.56 \pm 0.09$ & $1.60 \pm 0.14$ \\
Gelatin 10\% & $0.77 \pm 0.13$ & $0.87 \pm 0.54$ & $1.02 \pm 0.61$ & $1.29 \pm 0.22$ & $1.35 \pm 0.05$ & $1.52 \pm 0.04$ & $1.55 \pm 0.02$ & $1.60 \pm 0.01$ \\
culture medium & $0.48 \pm 0.29$ & $0.66 \pm 0.41$ & $0.85 \pm 0.55$ & $0.93 \pm 0.46$ & $1.17 \pm 0.12$ & $1.24 \pm 0.14$ & $1.43 \pm 0.04$ & $1.47 \pm 0.01$ \\
\hline
\end{tabular}

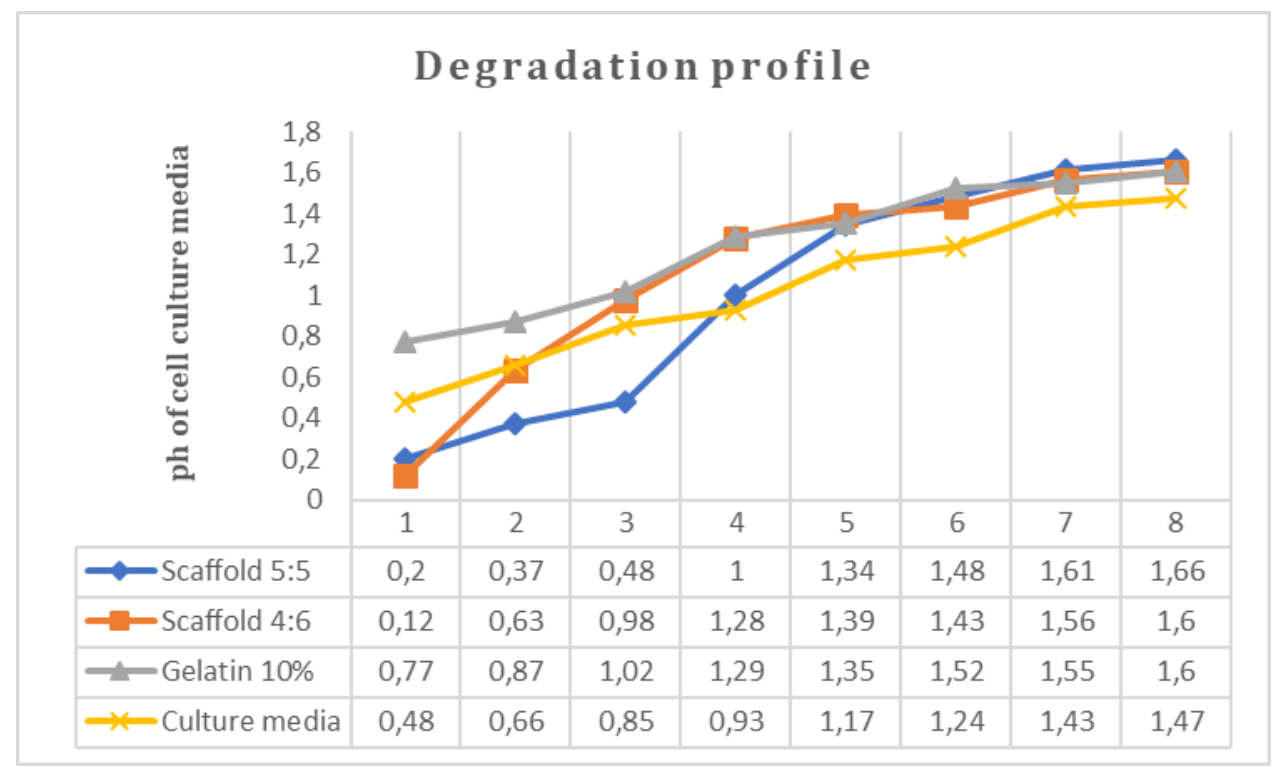

Fig. 2 Degradation Profile of synthetic coral scaffold in cell culture media

Table 2 One-way anova analysis

\begin{tabular}{cc}
\hline Day of immersion & significant \\
\hline 1 & $0.006^{*}$ \\
2 & 0.540 \\
3 & 0.598 \\
4 & 0.209 \\
5 & $0.037^{*}$ \\
6 & $0.011^{*}$ \\
7 & 0.06 \\
8 & 0.128 \\
\hline
\end{tabular}




\section{Discussions}

The result showed that increasing degradation from day 1 to day 8 presented degradability occurs with time. The mean of the highest $\mathrm{pH}$ on day 1 (shown in Table 1) was the gelatin $10 \%$ group. This showed that on day 1, gelatin $10 \%$ had the highest degradation compared to other groups. The hydrophilic properties of the gelatin $10 \%$ are capable of binding more water than the composition of gelatin scaffolds with CaC03. It is known that crosslinked scaffolds could enlarge for 3 days before become degraded, while pure gelatin scaffolds are completely degraded after \pm 16 hours of immersion [8]. In day 6 there was a significant difference between groups, and the highest $\mathrm{pH}$ was also in the gelatin $10 \%$ group.

The cell culture media is liquid that designed to support cell growth, in order for cells to live and proliferate [9]. This media usually contains inorganic salts (calcium chloride, ferric nitrate, calcium chloride, Magnesium Sulphate, Natrium Bicarbonate, Natrium chloride and Natrium Phosphate), D'Glukosa, Phenol red, amino acid (L-Arginine Hydrochloride, L-Cysteine.2HCl, L-Glutamine, Glycine, LHistidine.HCl.H2O, L-Isoleucine, L-leucine, L-Lysine Hidroksiklorida, L-Methionine, L-Phenylalanine, LSerin, L-Threonine, LTriptofan, L-Tyrosin.2Na.2H2O and L-Valine), Vitamin (D-Kalsium Pantothenate, Choline chloride, folic acid, L-Inositol, Niacinamide, Pyridoxine $\mathrm{HCl}$, Riboflavin dan Thiamine Hydrochloride) [10].

This study used DMEM cell culture media without phenol red because phenol red will change the color of the solution in case of increase or decrease in $\mathrm{pH}$. The color change due to phenol red will give the not accurate data because the color change it is difficult to distinguish the $\mathrm{pH}$ change of the cell culture media due to environmental factors of research or due to the effect of scaffold degradation [11].

The scaffold containing gelatin will swell when immersing in the liquid media. It indicates that the polymer in the scaffold is capable of absorbing the liquid without dissolving in it [8]. The scaffold polymer will swell gradually and begin to degrade when there is high hydration (highly swollen), because the force among molecule chains cannot restrain the force from the outside [12]. Degradation of the scaffold is influenced by several factors such as temperature, incubation duration, acidity level, solvent and crosslinking. These factors will influent the stability of the scaffold. The degradation process will continue to occur and increase until the scaffolds totally degraded [13]. The $\mathrm{pH}$ measurements were performed to determine the condition and amount of degradation. The higher of $\mathrm{pH}$ (alkali) shows the higher degradation. Gelatin is a polypeptide chain consisting of various amino acids which have zwitterion nature or dipolar because the chemical structure has a negative functional cluster (COO-) and positive functional cluster (NH3+). The amino acid is also amphoteric - it can be acid, neutral or alkaline based on the environment condition [14].

\section{Conclusions}

There is difference degradation profile of synthetic coral scaffold between 5:5; 4:6, and gelatin $10 \%$ composition. The synthetic coral scaffold degraded gradually until the end incubation time and between concentration had different degradation profile in the early incubation time using $\mathrm{pH}$ measurement.

Acknowledgments This project and publication were made possible by Faculty of Medicine and Health Science, Universitas Muhammadiyah Yogyakarta "kemitraan" research funding 2014. 


\section{References}

1. Tabata,Y.: Current status of regenerative medical therapy based on drug delivery technology. Reproductive BioMedinine Online 16 (I), 70-80 (2007). doi://doi.org/10.1016/S14726483(10)60558-5

2. Sachlos, E., Czernuszka, J.T.: Making tissue engineering scaffold work. Review: The application of solid freeform fabrication technology to the production of tissue engineering scaffolds. European Cells and Materials 5, 29-40 (2003). doi:10.22203/eCM

3. Kitamura, C., Nishihara, T., Terashita, M., Tabata, Y., Jimi, E., Washio, A., Hiratahi, S.: Regeneration approaches for dental pulp and periapical tissues with growth factor, biomaterials, and laser irradiation. Polymers 3(4), 1776-1793 (2011). doi://doi.org/10.3390/polym3041776

4. Gaikwad, V.V., Patil, A.B., Gaikwad, M.V.: Scaffold for drug delivery in tissue engineering. International Journal of Pharmaceutical Sciences and Nanotechnology 1(2), 113-122 (2008).

5. Ratanavaraporn, J., Damrongsakkul, S., Sanchavanakit, N., Banaprasert, T., Kanokpanont, S.: Comparison of gelatin and collagen scaffold for fibroblast cell culture. Journal of Metals, Materials and Minerals. 16(1), 31-36 (2006).

6. Hou, R., Chen, F., Yang, Y., Cheng, X., Gao, Z., Yang, H.O., Mao, T.: Comparative study between coralmesenchymal stem cells-rhBMP-2 composite and auto-bone-graft in rabbit critical-sized cranial defect model. Journal of Biomedical Materials 80(1), 85-93 (2007).

7. Mahanani, E.S., Bachtiar, I., Ana, I.D.: Human mesenchymal stem cells behavior on synthetic coral scaffold. Key Engineering Materials 696, 205-211 (2016). doi://doi.org/10.4028/www.scientific.net/KEM.696.205

8. Tronci, G.: Synthesis, characterization, and biological evaluation of gelatin-based scaffolds pp. 23-61. [Dissertation]. Mathematisch-Naturwissenschaftlichen Fakultät, Universität Potsdam (2010).

9. Freshney, R.I.: Culture of animal cells: A manual of basics technique and specialized applications, 6 th edition, pp. 125-148. John Wiley \& Sons, Inc., New York (2011).

10. Mather, J.P., Roberts, P.E.: Introduction to cell and tissue culture, pp. 41-62. Plenum Press, New York (1998).

11. Young, S., Wong, M., Tabata, Y., Mikos, A.G.: Gelatin as a delivery vehicle for the controlled release of bioactive molecules. Journal of Controlled Release 109(1-3), 256-274 (2005).

12. Guo, C., Gemeinhart, R.A.: Understanding the adsorption mechanism of chitosan onto poly(lactide-coglycolide) particles. European Journal of Pharmaceutics and Biopharmaceutics 70(2), 597-604 (2008).

13. Haugh, M.G., Murphy, C.M., McKiernan, R.C, Altenbuchner, C., Brien, F.J.O.: Crosslinking and mechanical properties significantly influence cell attachment, proliferation, and migration within collagen glycosaminoglycan scaffolds. Tissue Engineering Part A, 17(9-10), 1201-1208 (2011).

14. Winarno, F.G.: Kimia pangan dan gizi [Food chemistry and nutrition], pp. 136-153. Gramedia Pustaka Utama, Jakarta (2002). [in Bahasa Indonesia]. 